\title{
The function of Zechariah 7-8 within the book of Zechariah
}

\begin{abstract}
Authors:
Yohan $\mathrm{Im}^{1}$

Pieter M. Venter ${ }^{1}$

\section{Affiliations:}

${ }^{1}$ Department of Old

Testament Studies,

University of Pretoria,

South Africa

\section{Note:}

This article is a reworked version reproduced from an aspect in Yohan Im's PhD dissertation prepared under the supervision of Prof. Pieter M. Venter in the Department of Old Testament Studies, University of Pretoria, South Africa.
\end{abstract}

\section{Correspondence to: Yohan Im}

Email:

eljohn2000@gmail.com

\section{Postal address:}

Private Bag X20, Hatfield 0028, Pretoria, South Africa

\section{Dates:}

Received: 24 May 2013

Accepted: 29 July 2013

Published: 08 Oct. 2013

How to cite this article: Im, Y. \& Venter, PM., 2013, 'The function of Zechariah 7-8 within the book of Zechariah', HTS Teologiese Studies/Theological Studies 69(1), Art. \#2009, 10 pages. http://dx.doi.org/10.4102/ hts.v69i1.2009

\section{Copyright:}

C 2013. The Authors. Licensee: AOSIS OpenJournals. This work is licensed under the Creative Commons Attribution License.

Read online:
It is argued that the function of Zechariah 7-8 in the book of Zechariah is central to the issue of the structure of Zechariah. It is proposed that a text-linguistic approach offers a new reading of Zechariah 7-8. It is further proposed that the larger segment of Zechariah 7:1-8:23 is a bridge (a transition from the preceding discourse to the subsequent discourse) that is connected to the prologue in Zechariah 1:1-6 and is developed and expanded in the subsequent discourses. This reading indicates the structure and the overall theme of Zechariah by viewing the book as a sequential discourse. This argument will be defended by studying the structure and the overall theme of Zechariah and emphasising the holistic aspect of the book of Zechariah.

\section{Introduction}

To investigate the structure of Zechariah, the relationship between Zechariah 1-8 and 9-14 has to be considered (cf. Schaefer 1993:368; Redditt 2003:306). Many scholars have suggested that 1-8 and 9-14 are two separate corpora. The distinctions between 1-8 and 9-14 (cf. Hanson 1975; Plöger 1968; Redditt 2008:335) are based on the occurrence of the name of Zechariah in the first part of Zechariah $(1: 1,7 ; 7: 1,8)$ only and on some stylistic and lexical distinctions (cf. Boda 2003a:390, 2003b, 2003c; Coggins 1987:61-62). There are also scholars who read 9-14 as a continuation of 1-8. Their view on the unity or continuity between 1-8 and 9-14 is based on literary style, rhetorical form and lexical similarities (cf. Baldwin 1972:66-70; Butterworth 1992:272-275; Hartle 1992:145157; Kline 1991:179-193; Moseman 2000:487-498; Pierce 1984a:177-289, 1984b:401-411). Some scholars used tradition-historical features to examine the coherence between the two parts of Zechariah (cf. Childs 1979:482-483; Mason 1973:306, 1976:227-239; Meyers \& Meyers 1993:24-29), and still others used a form-critical method to find the continuity (cf. Floyd 2002:401-422; Portnoy \& Petersen 1984:11-21). Some scholars also used a literary and canonical approach to consider the final form of the text in their analyses (cf. Conrad 1999; Frolov 2005:13-40; Sweeney 2000:566-567).

This article argues that the function of Zechariah 7-8 is central to the issue of the structure of Zechariah. ${ }^{1}$ It proposes that a text-linguistic approach offers a new reading of $7-8$. This reading indicates the structure and the overall theme of Zechariah by viewing the book as a sequential discourse. The argument will be defended by studying the structure and the overall theme of Zechariah and by indicating the holistic nature of the book of Zechariah. ${ }^{2}$

\section{Investigation into the thematic development}

According to the text-level foregrounding ${ }^{3}$ (temporal deictic markers ${ }^{4}$ in Zch 1:1, 7 and 7:1 and cataphoric markers [משא] in 9:1 and 12:1), Zechariah can be divided as follows (cf. Floyd 2000:303, 2002:418-420; Moseman 2000:489): ${ }^{5}$

1:1-6:
1:7-6:15:
7:1-8:13:

1.Assis (2010:1-16) suggests that chapter 8 functions as a 'revision and digest' of Zechariah 1-7 by investigating the relationship between the ten oracles in 8 and their parallels in 1-7, and therefore, he sees 7 and 8 as separate units. As will be discussed later, the relationship between $1: 1-6$ and $1: 7-6: 15$ and the relationship between $1: 1-6$ and $7: 1-8: 23$ possibly reflect the relationship between $1-7$ and 8 as suggested by Assis. However, his observation overlooks $7-8$ as a thematic and coherent segment.

2.This article focuses on examining the holistic aspect of the structure of Zechariah. The structure and overall theme of Zechariah are to be examined from three aspects of the structure, namely the syntactic, thematic, and holistic aspects. See for a text-linguistic approach, Brown and Yule (1983); Lambrecht (1994); Goutsos (1997); Van der Merwe and Talstra (2003); Floor (2004); Hayes (2004).

3.The distinction between foreground and background in the discourse reflects the distinction between main part, leading part and side part (cf. Goldfajn 1998:73-89; Lowery 1985:144-145). The examination of foreground and background leads to finding sequential structures and hierarchical structure in a text. The text-level foreground indicates leading parts in a discourse at the long-range perspective.

4.Some scholars suggest a segmentation principle based on the 'significant breaks in the coherence of space, time, characters, events, and worlds' (Chafe 1979:180; cf. Givón 1990:896-897; Hwang 1989:462; Polanyi 1982:514; Segal, Duchan \& Scott 1991:32; Van Dijk \& Kintsch 1983:204). The markers, such as temporal markers (deictic as indicating what is prominent) and cataphoric markers, function as division or paragraph markers, demarcating linguistic individual units within a whole text.

5.For boundary marker or discourse marker, see Goutsos (1997:43); also cf. Clark (1985:328), Fraser (1990:383), Hayes (2004:114-115) and Miller (1999:167). For foreground and background, see Lowery (1985:144-145); also cf. Goldfajn (1998:73-89). 
9:1-11:17: משא : מoracle]

12:1-14: 21: משא; [oracle]

The next section indicates the connections between these larger segments by explaining the relationship between them. It describes the thematic flow and development between these larger segments by analysing the thematic development in the smaller segments from the perspective of topical and focal elements and their interrelationships in developing the themes. It shows how a theme in a preceding larger segment, carried by macro words or emphasised by syntactic configurations, is developed, expanded or elaborated upon.

\section{Thematic development in Zechariah 1:7-6:15}

Before investigating the relationship between Zechariah $1: 1-6$ and 1:7-6:15, it is necessary to consider the flow of the thematic development within 1:7-6:15.

The focus of the content ${ }^{6}$ (cf. Lambrecht 1994:336; Van der Merwe \& Talstra 2003:71-78) of the first vision in Zechariah 1:7-14a is the appearance of the world as ישבת ושיקת [sitting still and peaceful] (v. 11), confirmed by השאננים [who are at ease] (v. 15) on account of the control exercised by the man patrolling on a horse. This focus is reconfirmed and extended upon by the oracle in 1:14b-17. The appearance of the world, of all the nations, seemed to be true, but it turned out not to be what it seemed. In reality, the people of Judah groaned about their situation in which the nations were supposed to be judged by Yahweh but were seemingly not judged. However, the message to the people is that, because of Yahweh's wrath against the nations (1:15), judgement will surely be meted out. The local theme ${ }^{7}$ of 1:7-17 is the rebuilding of the house of Yahweh and the restoration of Jerusalem: Although the land seemed to be 'still and peaceful', Yahweh was angry with the nations. He comforts Jerusalem, saying that he will restore it in his mercy. Regarding the thematic development in the larger segment of 1:7-6:15, the segment of 1:7-14 functions as an introduction. As will be indicated, the themes in 1:7-14 are developed and articulated later in the segments of 2:1-6:15.

The local theme in Zechariah 2:1-4 (English ${ }^{8}$ 1:18-21) is the judgement against הגוים [the nations] that scattered Judah, but

6.According to information structure theory (see Lambrecht 1994), the theme and structure of the linguistic units (the smaller or larger segments) can be investigated by observing topics and focus structures. Lambrecht (1994:118; cf. Van der Merwe \& Talstra 2003:74) defines topics in terms of the relation of 'aboutness' between an entity and a proposition: 'The topic of a sentence is the thing which the proposition expressed by the sentence is ABOUT.' It is necessary to note in his definition of topic that topic is not about proposition itself but about 'a referent which stand in a certain relation to a proposition' (Lambrecht 1994:160). In this respect, hi definition of topic also includes topics such as framework or frame. Topic can play a role of connecting and relating segments as a framework in a text or discourse. Furthermore, Lambrecht differentiates three types of focus structure: (1) predicatefocus, (2) argument-focus and (3) sentence-focus (1994:221-223; for application to Biblical Hebrew, see Floor 2004:117-118; Hayes 2004:113-114, 2008:55-57; Van der Merwe \& Talstra 2003:68-107). He refers to 'focus structure' for indicating 'the conventional association of a focus meaning with a sentence form' (Lambrech 1994:222). In addition to these focus structures, other signals indicate that topics are in focus and are helpful to see how the local theme is developed in the linguistic units. The syntheses of these focus structures and other signals indicating that topics are in focus are called 'focus content'.

7.Kim (2002:137) distinguishes between local theme and global theme. This study employs 'local theme' for the theme of the smaller segments and 'global theme' for the theme of the larger segments or of the whole text when synthesising the themes of the larger segments.

8.English text (versification differs between English text and Hebrew text) they are to be terrified or cast down by הרשים [craftsmen].This theme flows from the preceding segment. The description of the judgement is more fully articulated in 2:1-4 than in the previous segment. Yahweh is angry with the nations that are at ease (1:15), and their judgement is specified: They will be scattered in exactly the same way that they scattered Judah and Israel. The local theme in 2:5-9 (Eng. 2:1-5) is the rebuilding of Jerusalem, indicated by the act of measuring. This theme also flows from the first vision in 1:7-17. However, in this segment (2:5-9, Eng. 2:1-5), the description of the rebuilding of Jerusalem is more elaborate and also focused upon by left-dislocation' (cf. Gundel 1988:51-54, 128; Van der Merwe, Naudé \& Kroeze 1999:339): ובהמה בתוכה פרוז תשב ירושלם מרב אדם [in open country, Jerusalem will be inhabited because of the many people and livestock in it]. In the subsequent oracle in 2:10-17 (Eng. 2:6-13), based on the promise that Yahweh will again choose Jerusalem and dwell amongst them, He exhorts his people to נסולטי [flee] and [escape] from Babylon and to רני ושמחי [sing and rejoice] (2:14; Eng. 2:10). These hortatory commands follow on the call in שובו 1:3 שreturn] to Yahweh.

The focus of the content of the segment in Zechariah 3:1-10 is on the clean turban on Joshua's head. The local theme here depicts the transformation or the removal of his filthy clothes and iniquities, clothing him with a clean turban on his head. The oracle in the subsequent segment in 3:6-10 confirms the meaning of the cleansing vision and the giving of exhortations to Joshua. Cleansing and forgiveness demand walking in Yahweh's ways and keeping his commandments (3:7). This exhortation is more elaborate than those in the preceding segments. The message to שובו [return] to Yahweh in 1:3 is elaborated upon in 2:10 and 11 (Eng. 2:6 and 7). It is still further elaborated upon in 3:1-10.

The focus of the content in the oracle regarding Zerubbabel is about the ידי שרבבל [hands of Zerubbabel], which may signify the role that Zerubbabel will play. His role is to finish the foundations of the house of Yahweh which he has already laid, as indicated in Zechariah 4:9. The local theme of the segment of 4:1-14 is that, whilst Yahweh will take control of all the land, בני היצהר [the two sons of oil] will play a significant role. These two sons are related to Joshua in 3:1-10 and to Zerubbabel in 4:6-10. In this respect, 3:1-10 and 4:1-14 are closely related, as indicated by 'the two sons' in $4: 14$. Both segments, namely 3:1-10 and 4:1-14, provide newly asserted information to the preceding segments. The roles of the king and the high priest to restore Yahweh's house, as indicated by 'the two sons of the oil,' are entrusted to Zerubbabel and Joshua, respectively. This is new information presented in both segments. However, these local themes in both segments are in line with the local themes of the preceding segments. The roles of Joshua as high priest and Zerubbabel as builder king (kingship) are likely to be an elaboration on the role of the 'craftsmen' in 2:3 (Eng. 1:20), who will scatter the nations exactly in the way the nations scattered Israel and Jerusalem.

9.'Right-dislocation' or 'left-dislocation' are the terms used in syntax to indicate a constituent occurring outside the clause boundaries either to its left or to its right. For example, in the sentence 'Mary and Tom,' they went to school, Mary and Tom is left-dislocated. 
The role of Zerubbabel as builder of Yahweh's house is likely to be an elaboration on the role of איש מדה [a measuring line] in 2:5 (Eng. 2:1). In this respect, these two segments function as an elaboration upon the preceding segments.

The local theme of the segment in Zechariah $5: 1-4$ is the judgement of sin. This theme connects with 3:1-10 where the local theme is the transformation from filthy to clean. In some sense, the local theme in both segments, namely 4:1-14 and $5: 1-4$, is an elaboration on the preceding segment of $3: 1-10$ where the local theme is developed in relation to the person of Joshua and indirectly related to the general judgement of sin. This is indicated by the expression הארצ ההיא ביומ אחד ומשתי את עון [I will remove the iniquity of that land in one day] in 3:9. The object of the judgement of $\sin$ is expanded to every thief and everyone who swears (falsely), being metonymies for the sinners throughout all of the land (cf. 5:3).

The segments of Zechariah 5:5-11 and 6:1-8 have a similar local theme. Both deal with the judgement against the nations who scattered Israel in 1:7-17. The range of Yahweh's judgement is expanded from Shinar (Babylon) in 5:11 to reach the whole earth in 6:5-8. The fact that Yahweh's judgement will go out in all directions (the whole earth) refers back to 1:7-17. In both segments, the image used is that of movement, such as horses that go out in every direction. The segment of 5:5-11 is related to the preceding segment of 5:1-4 in that both deal with sin. However, 5:5-11 develops a new aspect of this theme of sin. Whilst it emphasises that iniquity is pervasive throughout all of the earth, it signals the start of the judgement against Shinar (Babylon) in particular as indicated by the placing of האיפה [the ephah] in the land of Shinar. The next segment, 6:1-8, carries this theme further in that Yahweh's judgement will now be extended in all directions, to the north in particular.

The role of the segment of Zechariah 6:9-15 relates to the preceding segments in 1:7-6:15. Considering the recurrence of themes, this segment (6:9-15) is linked to 3:1-10. Joshua, as the secondary topic in 3:1-10, is reactivated in $6: 11$. The same happens with צמה [Shoot] in 6:12. The placing of the crown on Joshua's head $(6: 11)$ resembles the clean turban on his head (3:5). Zerubbabel is not specified in 6:9-15, but considering the role that 'Shoot' plays in building the house of Yahweh in 6:12, this segment is linked to 4:9, although 'Shoot's' role here is more than what Zerubbabel did in 4:1-14. The local theme in the segment of 6:9-15, the rebuilding of Yahweh's house and the restoration of Jerusalem, is connected to the first segment (1:7-17) within the larger segment of 1:7-6:15 and even to the prologue in the first larger segment of 1:1-6. The reason why the segment of 6:9-15 is placed after the series of smaller segments (1:7-6:15) in which the local themes are about judgement on sin and the nations has to be considered from the long-range discourse perspective. It is likely that the true rebuilding of the house of Yahweh and the restoration of Jerusalem, and of Judah-Israel, will be accomplished through God's judgement on sin. Therefore, the last closing

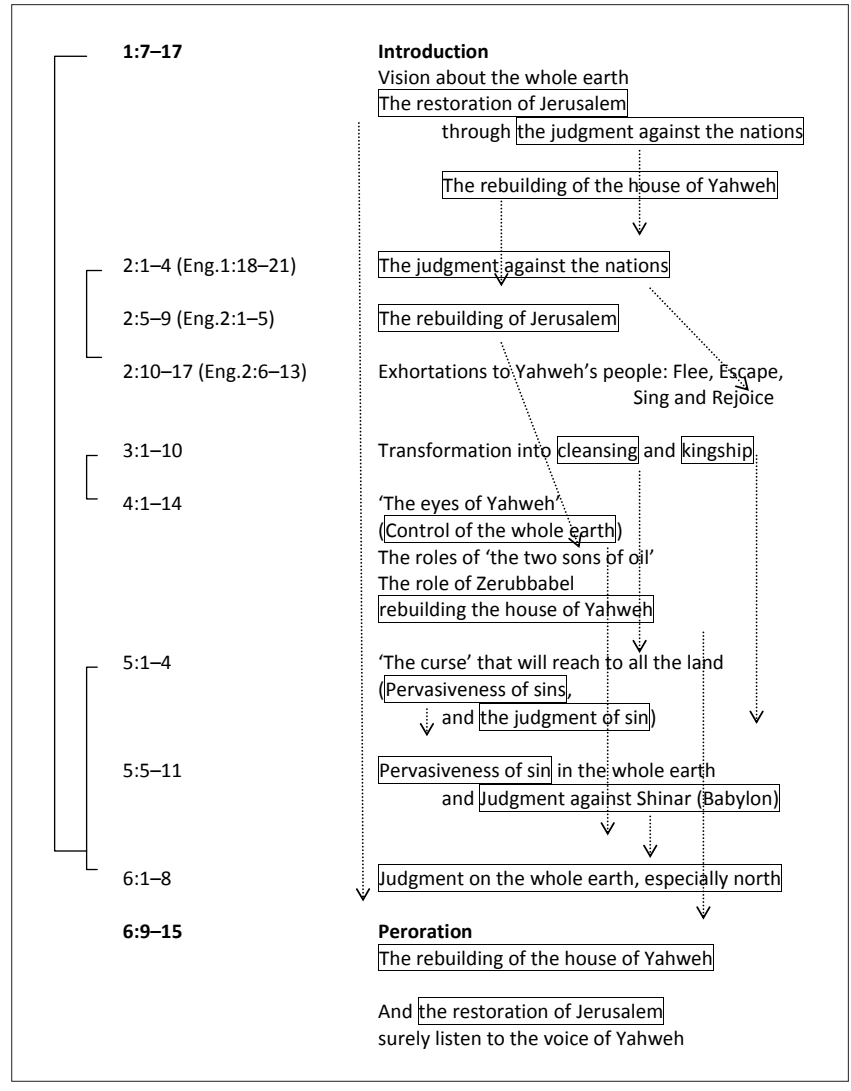

FIGURE 1: 1:7-6:15: Visions and oracles.

remark in this segment provides an exhortation to his people: [והיה אם שמוע תשמען בקול שהוה [It will happen if you surely listen to the voice of Yahweh] (6:15). This exhortation repeats the exhortations of the larger segment of 1:7-6:15. Therefore, 6:915 functions as a closing summary or peroration to the larger segment, namely 1:7-6:15.

The interrelationships between segments within the larger segment of Zechariah 1:7-6:15 is summarised in Figure 1. ${ }^{10}$

\section{The relationship between Zechariah 1:1-6 and 1:7-6:15}

The theme of Zechariah 1:1-6 is exhortation and promise, namely 'return to Yahweh from your evil ways and from your evil doings' as well as 'Yahweh's return to them'. This message was already delivered to אבותיכם [your fathers], but they did not listen and did not pay attention to him. As a result of their lack of attention, Yahweh was angry with them, and his words caught up with them. The same message is delivered to the generation of Zechariah: שובו אלי ... ואשו אליכם [return to me ... and I will return to you] (1:3). The focal element in this segment is Yahweh's anger towards their fathers who did not listen to him and their disobedience consequently being punished. This theme of returning to Yahweh recurs and is developed in the subsequent discourses. The relationship between this larger

10.The blocked words below signify the summarised and shortened key words for the segment. By observing the interconnections between those blocked words, it is possible to see the flow of the thematic development. 
segment (1:1-6) and the next larger segment, 1:7-6:15, is described in terms of returning to Yahweh.

Most of the segments within the larger segment of Zechariah 1:7-6:15 expand and develop the themes of segment 1:1-6. Zechariah 1:7-17 is closely related to 1:1-6. The macro words of שובוב [return] and I will return] (1:3) to Yahweh in 1:1-6 recurs again in 1:7-17: ברחמים שבתי לירושלם, [I returned to Jerusalem with mercies] (v. 16). The wrath of Yahweh in 1:2 recurs in 1:15. In the meanwhile, the theme of Yahweh's returning to his people in 1:1-6 is developed into the building of the house of Yahweh (1:16), the restoration of Jerusalem by again choosing Jerusalem (1:17) and Yahweh's wrath against the nations (1:15). In this way, the theme in 1:7-17 is an elaboration of the theme of Yahweh's returning to his people in 1:1-6. These expanded themes in 1:7-17 are developed and expanded in the subsequent discourses $(2: 1-6: 15)^{11}$ as discussed in the previous section. In this way, the themes of the larger segment of 1:1-6 recur and are developed in the subsequent larger segments of 1:7-6:15 to elaborate on the prologue (1:1-6). The oracle in the segment of $6: 9-15$ is the peroration that closes the whole section of eight visions with their oracles in 1:1-6:15:

$\begin{array}{ll}\text { 1:1-6: } & \text { Prologue } \\ \text { 1:7-6:8: } & \text { Development to the prologue } \\ \text { 6:9-15: } & \text { Peroration }\end{array}$

\section{Thematic development in Zechariah 7:1-8:23}

The flow of the thematic development in the preceding two larger segments (Zch 1:1-6 and 1:7-6:15) shows that the smaller segments within the larger segments are closely related and connected by common themes amongst the smaller segments. However, the style in this larger segment is different. The discourse marker ויהי [and then] connects it with the preceding discourse, but it also indicates the development of a new scene or a new theme (cf. Van der Merwe et al. 1999:331). The smaller segments within Zechariah 7:1-8:23 are interrelated and form a thematic unit (the larger segment):
7:1-7:
Fasting for themselves not for Yahweh
7:8-14: Their stubbornness and desolation for not listening
$8: 1-17:$ Exhortations of Yahweh to follow based on the promise of the restoration of Jerusalem
8:18-23: Another aspect of restoration:
Many nations will come to Yahweh

The first smaller segment (Zch 7:1-7) and the last segment כי צמתם (8:18-23) are linked by the macro word fasting, namely [when you fasted] and הצום צמתני אני [שום [did you really fast for me] in 7:5 and צום הרביעי וצום החמישי וצום השביעי וצום העשירי [the fourth, the fifth, the seventh, and the tenth fast] in Zechariah 8:19. ${ }^{12}$ Centring on the issue of 'fasting', 1:1-7 and 8:18-23 develop the theme of the way of Yahweh's restoration. The first two segments are related in that both segments deal

11.The relationship between Zechariah 1:1-6 and 1:7-17 implies a further relationship between 1:1-6 and 1:7-6:15.

12.Van Dyke Parunak (1983:526) suggests that there are transitional techniques to connect 'the segments of text into larger units'. He pays special attention to the 'patterns of repetition and similarity among the units that make up its surface texture' and suggests 'link' and 'hinge' as transitional techniques. See for macro word, Floor (2004:217) with what Israel had done in the past and their stubbornness. The third segment urges Israel to return from the past days whilst emphasising that Yahweh has returned and dwells amongst them. It also refers to the difference between what was done to them in the past and what Yahweh is doing [on those days] according to the word of Yahweh. Two imperatives, 'let your hands be strong', in 8:9 and 13, and 'do not fear', in 8:13 and 15, strengthen their confidence to do what Yahweh says. What they have to do is spelled out in 8:16-17 as a summary statement. The last segment, 8:18-23, introduces another aspect of the restoration 'on those days', namely that many nations will come to seek Yahweh in Jerusalem. Zechariah 8:18-23 elaborates on 8:1-17 with this new aspect of the restoration of the relationship between Yahweh and Judah. The global theme of the larger segment, 7:1-8:23, is summarised as: In days past, his people were stubborn and disobedient to Yahweh, but now and in the future (on those days), they need to return from their past ways and live according to the word of Yahweh because Yahweh restored his relationship with them, and he restored Jerusalem.

\section{The relationship between Zechariah1:1-6 and 7:1-8:23}

The relationship between Zechariah 1:1-6 and 7:1-8:23 clarifies the role of the larger segment of 7:1-8:23.

The theme of Zechariah 1:1-6 is the message to 'return' to Yahweh. This message was first delivered to Israel's forefathers by the former prophets and then to Zechariah's generation. This exhortation to return to Yahweh is based on the promise that Yahweh will return to his people. This theme recurs in the larger segment of 7:1-8:23. The themes of the stubbornness and disobedience of the fathers are repeatedly mentioned in 7:11-13. It caused the judgement that scattered them amongst the nations as indicated in 7:14. The exhortations in 8:16-17 and those expressed by the imperatives in 8:9,13 and 15 are reminiscent of the exhortation 'return to me' in 1:3. The local theme of Yahweh's returning to his people also recurs in 7:1-8:23 and elaborates on the future days in contrast to the past, telling what Yahweh will do for his people and the nations. In this way, it is suggested that 7:1-8:23 are linked with 1:1-6 by the recurrence of similar themes in both segments. ${ }^{13}$

\section{Thematic development in Zechariah 9:1-11:17}

The local themes in the different segments are as follows:

9:1-8: $\quad$ Judgment against the nations

The eyes of men are looking up to Yahweh while the eyes of Yahweh will be watching and protecting

9:9-17: Rejoice $^{14}$ and Return

The promise of restoration by Yahweh through 'king.'

13.Aspect of the future days will be articulated and developed later in the segments (Zch 9:1-14:21).

14.As in Zechariah 2:14 ('rejoice'), the expressions 'rejoice' and 'shout' in 9:9 is not a direct exhortation expression, but it is another expression of trust in Yahweh based on the promise of Yahweh: 'Your king is coming to you, righteous and victorious' (Zch 9:9). 
10:1-12:

Ask from Yahweh.

He is the only one who will restore

and make His people strong

11:1-17: Judgment message to His people and the shepherds (leader)

This larger segment (Zch 9:1-11:17) has a chiastic structure. The first smaller segment starts with the judgement against the nations. The reason for the judgement against the nations in Zechariah 9:1-7 is given in 9:8: 'For the eyes of men are on Yahweh, and all the tribes of Israel.' In the last segment (11:1-17), another aspect of judgement is introduced, the judgement of Yahweh on his people and their leaders. In its centre is the second smaller segment of 9:9-17 and the third one of 10:1-12. Both segments, where imperatives play a significant role as hortatory remarks, have a similar discourse structure with the imperative in the initial position of the segments and the reasons for the exhortations indicated by the series of כי [because of]. Considering imperatives in the initial position of the segments, the global theme in this larger segment is found in the imperative verbs: גילי [rejoice] in verse 9, שובו [return] in verse 12 in 9:9-17 and שיהו [ask from Yahweh] in 10:1-12. ${ }^{15}$ The local themes of the first and last smaller segments are about the judgement against the nations and Yahweh's people. These themes are likely to be the ground for exhortations to 'return' and 'ask from Yahweh,' that is, the local themes in the second and third smaller segments.

\section{Thematic development in Zechariah 12:1-14:21}

The local themes in the segments can be divided as follows:

\begin{tabular}{|c|c|}
\hline 12:1-8: & $\begin{array}{l}\text { Yahweh will make Jerusalem 'a cup of } \\
\text { staggering' } \\
\text { to her attackers (Blessing on Jerusalem) }\end{array}$ \\
\hline 12:9-13:1: & $\begin{array}{l}\text { Pouring out 'a spirit of grace and petition' and } \\
\text { 'mourning' } \\
\text { (Cleansing of Jerusalem) }\end{array}$ \\
\hline 13:2-9: & $\begin{array}{l}\text { Restoration of the relationship } \\
\text { between Yahweh and the rest of His People } \\
\text { After judgment on the prophets (leaders) } \\
\text { and to all the land }\end{array}$ \\
\hline 14:1-21: & The coming of the day of Yahweh \\
\hline 14:1-5: & The coming of the day of Yahweh as a warrior \\
\hline 14:6-11: & The day of Yahweh as King of the whole earth \\
\hline 14:12-15: & $\begin{array}{l}\text { The day of Yahweh as Judgment } \\
\text { on the attackers of Jerusalem }\end{array}$ \\
\hline 14:16-21: & Worship to Yahweh on that day \\
\hline
\end{tabular}

The subdivisions in this segment are all in a chiastic structure. The first segment starts with the message that Yahweh will make Jerusalem סף [a cup of staggering], which means that Yahweh will make Jerusalem so strong that the nations will stagger. However, this victory of Jerusalem will take place when Yahweh comes and cleans through his spirit of grace. His spirit will come over them, leading to their repentance as indicated by the subsequent segment (Zch 12:9-13:1). The third segment (13:2-9) also starts with the judgement message to the prophets (leaders) and to all in the land. In this respect, the second and third segments (12:9-13:1 and 13:2-9) deal Beekman, Callow \& Kopesec 1981:36-37). with the relationship between Yahweh and his people, and the third elaborates on the preceding segment. The theme of the last segment (14:1-21) reflects the theme of the first segment: Yahweh wins the battle for Jerusalem (14:1-5). This segment (14:1-21) is the climax of the larger segment. The expression 'on that day' occurs very often in this segment whilst it occurs sometimes in the preceding segments. The repetition of this expression in previous sections looks forward to 'on that day.' The last segment, Zechariah 14:121, starts with the expression יום בא ליהוה ' [a day of Yahweh is coming] in 14:1 in a participle clause to signal the imminence of the day's coming. The subsequent discourses (14:1-21) develop various aspects of the day of Yahweh that lead up to everything worshipping Yahweh 'on that day', even the remnant of nations that fought against Jerusalem in the final battle. Considering the repetitive expression of 'on that day', the thematic flow of this larger segment, namely 12:1-14:21, and the function of the last smaller segment of 12:1-14:21 as a climax of the larger segment of 12:1-14:21, the global theme of this larger segment focuses on what Yahweh is going to do 'on that day'.

\section{The relationship between Zechariah 7:1-8:23 and Zechariah 9:1-14:21}

The role of Zechariah $7: 1-8: 23$ as an introduction is confirmed by the observations of the interrelationship with the subsequent segments (cf. Boda 2003a:405-406). Both subsequent segments, 9:1-11:17 and 12:1-14:21, have their own linguistic features. In the segment of 9:1-11:17, exhortations in the form of imperatives occur in both centre segments. In the segment of 12:1-14:21, the expression 'on that day' occurs very often. These features, the exhortations and the emphasis on 'on that day' (signifying the future restoration and blessings), develop and elaborate the themes in 7:1-8:23. In this respect, 7:1-8:23 is the introduction to the developments and expansions in 9:1-11:17 and 12:1-14:21.

The smaller segments of Zechariah 9:1-8 and 11:1-17 within the larger segment of 9:1-11:17, with their local themes of judgement against the nations and Israel, develop the segments of $7: 1-7$ and $7: 8-14$ which belong to the larger segment of 7:1-8:23. These local themes are also elaborated upon in the subsequent segments (9:1-14:21). The judgement will surely happen to the extent that the eyes of men will look up to Yahweh (9:1). The judgemental messages to his people and the shepherds (leaders) are articulated by Zechariah's symbolic act in the segment of 11:1-17. The theme of judgement recurs in the last segment of 12:1-14:21, in which most of the local themes of the segments are about the restoration 'on that day'. The judgemental messages against $\sin$ are repeated in the last segment of 12:1-14:21. The local theme of cleansing, which will be fulfilled by Yahweh's pouring out רח חן ותחנונים [a spirit of grace and petition] in $12: 10(12: 9-13: 1)$, is also repeated.

In the same way, the local themes of exhortations to his people in the segments of Zechariah 9:9-17 and 10:1-12 build on the segment of 7:1-8:23 and develop those themes. The 
גילי גי גיל [rejoice] in 9:9 and to שובו [return] in 9:12 in the segment of 9:1-17 are based on the promise of the restoration by Yahweh through מלכך [your king] in 9:9. In a similar way, the exhortation to שאלו מיהוה [לכך [ask from Yahweh] in the segment of 10:1-12 is given because Yahweh is the only one who will restore his people and make them strong.

The local theme of restoration occurs very often in the last segment of Zechariah 12:1-14:21, following on the segment of $7: 1-8: 23$. In the introduction $(7: 1-8: 23)$ to the subsequent discourse (9:1-41:21), the local theme of restoration, what Yahweh will do for his people בשמים ההם [on those days] in 8:6 is briefly introduced. In the segment of 12:1-14:21, various aspects of restoration ביום ההוא [on that day] are articulated.

In this way, Zechariah 7:1-8:23 (cf. Figure 2) is an introduction to the subsequent discourses in 9:1-14:21 to raise the reader's expectation of what Yahweh is going to do 'on those days' (cf. Boda 2003a:402-405; Kline 1991:184; Meyers \& Meyers 1987:i-iv; Tollington 1993:208-209).

\section{Thematic development in Zechariah as a whole}

According to the text-level deictic markers (cf. Hayes 2004:114-115), the book of Zechariah can be divided into five major segments $(1: 1-6 ; 1: 7-6: 15 ; 7: 1-8: 13 ; 9: 1-11: 17$; 12:1-14:21). These discourse markers play a significant role to demarcate the segments within the whole text of Zechariah. In terms of communication between the author and the readers (or audience), these markers help readers to understand the total text by dividing it into smaller parts and at the same time guiding the readers in its directions. Temporal deictic markers place the readers within the historical context, and occurrences of series of these temporal deictic markers indicate the continuity of the themes. The readers grow in their expectation of the climax as the discourses develop within 1:1-8:23.

Next there is a sudden change of discourse markers. Without any temporal deictic markers, the expression משא [claim] occurs in Zechariah 9:1 and 12:1 (Moseman 2000:489-490). The change of linguistic features such as discourse markers signals the possible change of discourse with the emphasis on the focus marker. In this respect, there is a transition from the former part (1:1-8:23) to the latter part (9:1-14:21).

The larger segments of Zechariah 1:1-6:15 (1:1-6 and 1:7$6: 15)$ have their own thematic structure with the prologue (1:1-6), and the developments of the prologue in 1:7-6:8 and a peroration (6:9-15). In the same way, the latter part of Zechariah with its larger segments (7:1-8:23, 9:1-11:17 and 12:1-14:21) have a thematic structure: Introduction, development of the introduction and further development of the introduction leading up to the climax. The overall structure of the thematic development of Zechariah as a whole can be seen in Figure 3.

\section{Discussion of structure}

Kline (1991:179-193) suggests that the book of Zechariah can be understood as a diptych with Zechariah 6:9-15 as a

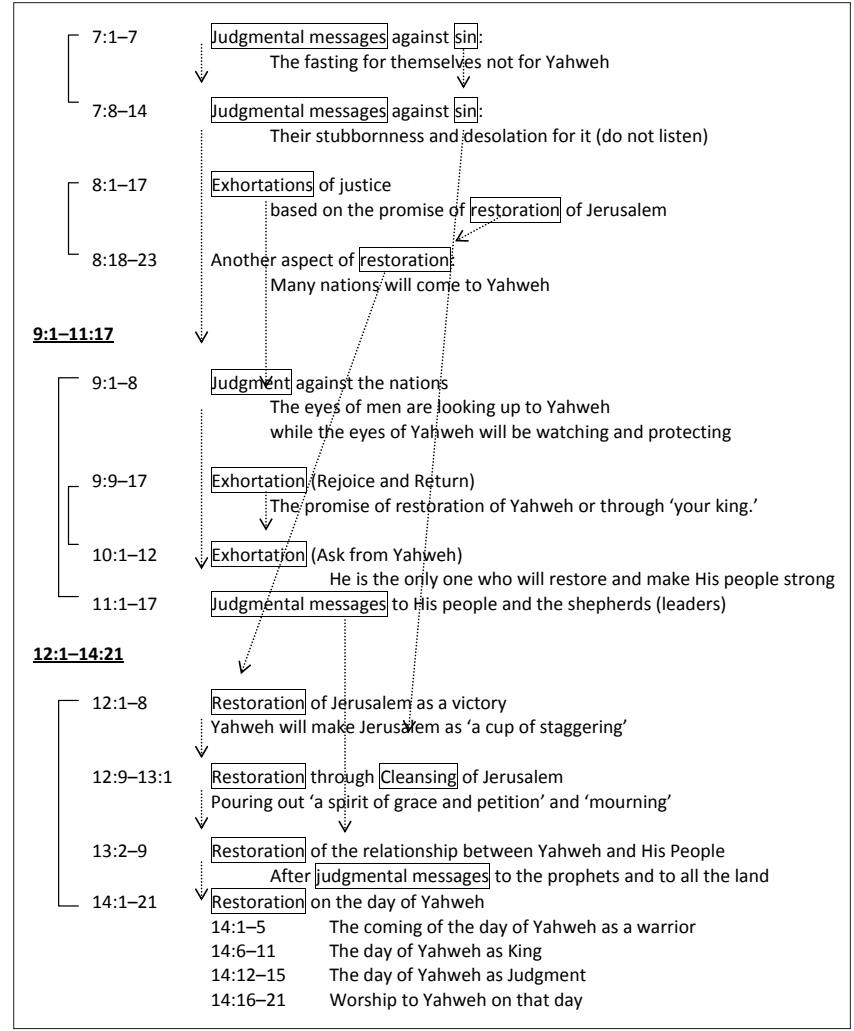

FIGURE 2: 7:1-8:23 Bridge (Transition).

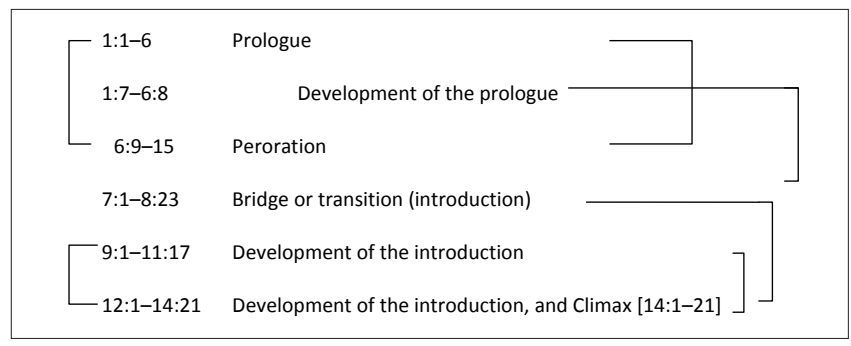

FIGURE 3: Overall structure of Zechariah.

hinge. He is further of the opinion that the major two sections (1:1-6:8 and 7:1-14:21) are divided by other hinges (3:1-10 and 11:1-17). These three hinges consist of the symbolic acts of Zechariah. However, as Frolov (2005:16) points out, his structural analysis is not based on the structural markers.

Conrad (1999:131) contends that Zechariah is divided into three parts, namely $1: 1-6,1: 7-6: 15$ and 7:1-14:21, based on the date expressions. In his structural analysis, he suggests that the whole structure of Zechariah is based on questions and answers. There are questions and answers in 1:1-6 and 1:7-6:15. The question stated in 7:23 by the messenger Zechariah is answered partially in 7:4-14. The two oracles in 9:1-11:17 and 12:1-14:21 are the answer to the question in 8:6 (Conrad 1999:153-154). However, I do not agree that the question and answer function as framework to construct the whole structure in Zechariah. The question in 1:5 is more like a rhetorical question, and the answer in 1:6 is not exactly the answer to the question in 1:5. Furthermore, this question does not function as a framework for structuring שובו אלי 1:1-6. The focus of this segment is on the message of [return to me]. This message is given to challenge Yahweh's 
people to commit themselves to the word of Yahweh. Also, [my words and my statues] in 1:6 reflects the word of Yahweh whilst אבותיכם [your fathers] are mentioned for the purpose of counter-example for the current generation not to follow. In this way, the rhetorical question (1:5) and following statement (1:6) are additional remarks to emphasise the main message of Yahweh, 'return to $\mathrm{me}^{\prime}$, rather than the framework for the segment of 1:1-6. In the same way, the questions in 1:7-6:15 do not seem to function as a structural framework. It is true that the visions and oracular parts are given by questions and answers, but these questions and answers are only rhetorical devices to deliver more vividly the visions and oracular parts in 1:7-6:15. The question in 8:6 seems to be a rhetorical question and does not control the subsequent discourses. It is suggested that 7:1$8: 23$ as a thematic unit sets an introduction to the subsequent discourses (9:1-14:21). In this respect, it is not likely that the whole structure of Zechariah is constructed by the question and answer, and it is not likely that the relationship between 7-8 and 9-14 can be understood as question and answers.

Like Conrad (1999), Sweeney (2000:636) divides Zechariah into three parts: 1:1-6, 1:7-6:15 and 7:1-14:21. In Conrad's analysis of $7: 1-14: 21,9: 1-14: 21$ is the answer to the question in 8:6, but Sweeney (2000:636) suggests a close relationship between 8:18-23 and 9:1-14:21: Whereas 8:18-23 indicates that the nations will ultimately recognise Yahweh in Jerusalem, 9-11 and 12-14 provide a detailed scenario of the process by which this recognition will take place. Furthermore, Sweeney (2000:636) argues that 8:18-14:21 as a unit provide the prophet's final answer to the initial question in $7: 1-7$ concerning the need for continued mourning. However, I suggest that 7:1-8:23 is a coherent and thematic unit and that this unit as larger segment develops a global theme within it. This global theme is developed and expanded in the subsequent discourses in 9:1-14:21. The question in 7:2-3, given in a narrative framework, is answered indirectly in 8:18-23 whilst discourses concerning the question are still developing in 7:5-7, 8:1-8 and 8:9-17. Besides, Sweeny's analysis overlooks the discourse markers such as temporal deictic markers (1:1, 1:7 and 7:1) and the cataphoric markers משא [claim] in 9:1 and 12:1) to demarcate the segments within the whole of the book of Zechariah. Frolov's (2005:16) critique on Kline (1991:179-193) applies to Sweeney's argument on the division of Zechariah as well.

Floyd's (2000, 2002) structural analysis of Zechariah is very similar to that of mine. He divides Zechariah into five parts: 1:1-6, 1:7-6:15, 7:1-8:23, 9:1-11:17 and 12:1-14:21. He pays attention to date markers (1:1, 7 and 7:1) and משא [claim] (9:1 and 12:1) for structuring Zechariah. The difference with his analysis is in his division based on the use of משא. Floyd (2002:401-422) asserts that the משזא in Zechariah relates chapters $9-11$ and $12-14$ to the preceding chapters. The function of the segments of משא is, according to Floyd (2002):

... to reinterpret what the prophet Zechariah discerned regarding Yahweh's involvement in the restoration of Yehud in the early Persian period, elaborating on its implications for the discernment of Yahweh's involvement in the events of a later time. (pp. 418-420)
His division of Zechariah is not based on the synchronic dimension but on 'essentially diachronic interpretational frameworks' (Frolov 2005:15).

Frolov (2005) divides Zechariah into three parts, namely 1:1-6, 1:7-6:15, and 7:1-14:21, based on the date expression markers (1:1, 7 and 7:1). The purpose of his analysis is 'a genuinely integrated and coherent reading of Zechariah by adequately accounting for the peculiarities of the book's form and content in a strictly synchronic perspective' (Frolov 2005:17). By focusing on the formal layout, especially whilst characterising Zechariah within the overall narrative framework and observing that she or he mentions him or herself in the third person, he identifies different voices in the book of Zechariah: Zechariah and the narrator. Based on these findings, he attempts to harmonise the differences between 1-8 and 9-14. Especially by identifying 8:18-14:21 as the final response of the narrator, he explains why there is no Zechariah in 9-14. His findings on the overall narrative framework in Zechariah are partially correct. Although the overall book of Zechariah does not display the characteristics of a narrative framework, many of segments in the book of Zechariah display these narrative frameworks. The last part of Zechariah in 9-14 mostly consists of a series of oracles. Therefore, it is not easy to identify a narrative framework in this part. Besides, the observations of mentioning him or herself in the third person are not an absolute standard to identify those expressions as different voices. As Frolov (2005:18) himself points out, Ezekiel himself identifies himself in the third person in Ezekiel 1:3. When Yahweh is mentioned in the third person, those speeches are often considered as Yahweh's direct speech (7:7-14).

Boda (2003a) suggests that Zechariah 7-8 functions as a bridge in its literary function within Zechariah as a whole. His analysis of the structure of 7-8 within the book of Zechariah is similar to mine on the discourse structure in the book of Zechariah. The difference is that, according to Boda (2003a, 2004), there is a contrast between 1-8 and 9-14. He identifies 1-8 as 'realised' and 9-14 as 'frustrated' (Boda 2003a:407), in other words, 'positive focus on the present' for 1-8 and 'eschatological hopes and warnings' for 9-14 (Boda 2003a:393). Meanwhile, 7-8 functions as connecting and harmonising both 1-6 and 9-14 by preparing for the subsequent discourses (9-14) because there is contrast in the focus of each part. In the former part (1-6), the focus is on the present failure of Zerubbabel in building the house of Yahweh. The new age has not come yet. To appease the present failure, the last part (9-14) focuses on the eschatological aspect of the message such as the building of the house of Yahweh and the restoration (cf. Petterson 2009:14-16). Boda's suggestion on the relationship between 1-8 and 9-14 is based on the identification of צמח [Shoot] or שני בני היצהר [two sons of oil] as Zerubbabel or specific persons. Similarly, Moseman (2009:575-589) explains the unity between 1-8 and 9-14 by focusing on the differences between them, especially focusing on the date formulae. He argues that 'Zechariah 9-14 is set forth as a replacement prophecy that envisions future judgement and punishment 
and a new house of Yahweh' (Moseman 2009:583). I do not agree with the contrast between 1-8 and 9-14. There is a different emphasis in each part because 1-8 tend to focus on the present whilst 9-14 focus on the future. However, in the first part of Zechariah, the aspect of indicating the future restoration from Yahweh also features. Although repetitive remarks on 'on that day' occur in the last part of Zechariah, ${ }^{16}$ there are some remarks on 'on that day' that relate the first part ('on that day' in 2:15; 3:10 and 'on those days' in 8:23) to the last part of Zechariah $(9: 16 ; 12: 3,4,6,8,9,11 ; 13: 1,2$, $4 ; 14: 4,6,8,9,13,20,21)$. This implies that there is already a promise of future restoration by Yahweh in the first part of Zechariah.

Boda argues that 'Shoot' or 'two sons of oil' are to be identified as specific persons and that the passages mentioning these terms are related to the present. However, there is another possibility: One cannot identify these terms with specific persons. These terms are related to what Yahweh will do to his people in future. In this respect, it is likely that the emphasis of the first part of Zechariah is on the present, but simultaneously, the first part of Zechariah also contains the aspect of mentioning the future restoration of Yahweh.

At this stage, it is necessary to consider some arguments on the identity of 'Shoot' and 'two sons of oil'. The issue of the identity of 'Shoot' and 'two sons of oil' is not related to structural matters but to the arguments on how the identity influences the view of the structure of Zechariah, the relationship between Zechariah 1-8 and 9-14 and the function of 7-8 in particular. The identity of 'Shoot' and 'two sons of oil' is very significant. When these are identified as specific persons, Joshua and Zerubbabel, it is likely that the focus in $1-8$ is on the present situation, which implies a stark contrast between 1-8 and 9-14. Their role in the restoration of Israel was emphasised in the former part (1-8), and then in the last part (9-14), they disappear. In this regard, there has been much discussion amongst scholars. The main issues concerning 'Shoot' and 'two sons of oil' are summarised as follows: One view considers them as specific persons (Joshua and Zerubbabel) whilst the other view considers them as future figures. Both of these views are related to how the various scholars see the relationship between 1-8 and 9-14. The former view contends that there is a stark contrast between 1-8 and 9-14. For example, Boda (2003a, 2004) identifies 'Shoot' as Zerubbabel though there are difficulties, and on this ground, he asserts the contrast between 1-8 and 9-14. The promise was given that Zerubbabel will build the house of Yahweh (4:8) and thereby restore Israel. However, the historical reality was different. Zerubbabel disappeared in history seemingly without realising this promise. For this reason, according to Boda (2003a, 2004), 9-14 was added, and 7-8 was inserted for the purpose of preparing the future eschatological message in 9-14. Some scholars also identify 'two sons of the oil' (4:14) as Zerubbabel and Joshua or two offices that they took by translating it as 'the anointed sons'. Redditt (1995:66) also attempted to identify 'Shoot' as Joshua.

16.These repetitive remarks of 'on that day' in the last part of Zechariah, 14:1-21 in particular, are explained by arguing that 14:1-21 function as a climax in its thematic development of discourse.
I agree with the investigation of Zechariah 9-14 that focuses on the eschatological aspect and with the function of 7-8 as a bridge between 1-6 and 9-14 (cf. Boda 2003a, 2004). However, I do not agree with the claim that the focus of $1-8$ is on the present. As mentioned earlier, there is a difference between 1-8 and 9-14 in its emphasis on the eschatological 'on that day'. However, the early part of the book (1-8) does have a perspective on the eschatological 'on that day' as mentioned above.

The literary context reveals that Joshua and Zerubbabel cannot be considered to be 'Shoot.' Zechariah 3:8 says that Yahweh promises Joshua that he will send the Shoot. This indicates that Joshua is not a Shoot. Zechariah 3:9-10 indicates that 'Shoot' will come in the future and will bring an age of cleansing and prosperity. This does not fit Zerubbabel either because it is beyond what Zerubbabel does (Petterson 2009:98-99). Whilst both of them cannot be identified with 'Shoot', their roles contribute to the future coming of 'Shoot' and are symbolically related to the role of 'Shoot' (Baldwin 1972:135). In a similar way, 'two sons of oil' is likely to be related to the role that Zerubbabel (or both Joshua and Zerubbabel) will play rather than identifying one or both of them. Just as 'shoot' is not identified as Joshua in 3:1-10 so 'two sons of the oil' does not seem to be identified as specific persons, namely Joshua and Zerubbabel.

From the observation of the thematic flow or development in the literary context that 'Shoot' or 'two sons of oil' will appear, the focus of these words and phrases is on the role they will play in relation to the priest and the king in future. Zechariah 3 is about cleansing and a promise for prosperity that 'Shoot' will bring (Smith 1984:199), which is also the preparation for the building of the house of Yahweh or the restoration of Israel. Zechariah 6 is also about the confirmation of the promise of restoration through a future figure. In 4 where Zerubbabel is mentioned, the focus is not on Zerubbabel who will finish the building of the house of Yahweh but on the power of Yahweh who will ultimately make it possible to build the house of Yahweh (Petterson 2009:69). In addition, in 4:14, 'two sons of the oil' are identified as העמדים על אדון כל הערץ [who are standing by the Lord of all the land]. The expression 'who are standing by the Lord of all the land' is paraphrased as מהתיצב על אדון כל הארץ [from who are standing themselves before the Lord of all the land] in 6:5. Their role is related to the future. In this respect, the role of 'two sons of oil' is not likely limited to the role of the specific persons Joshua and Zerubbabel. The role of 'two sons of oil' is beyond what they will do.

In this way, the focus is not on specific persons, Joshua or Zerubbabel, but on the role that is related to these two figures, symbolising the roles of specific persons, Joshua or Zerubbabel, in the future - the significant theme such as the building of the house of Yahweh or Israel's restoration in future. Basically, I agree with Boda's (2003a) investigation of the role of 7-8 as a bridge between 1-6 and 9-14, but in 
details, I disagree with him whilst contending that there is continuity between 1-8 and 9-14, and the role of 7-8 is not harmonising the stark contrast between 1-6 and 9-14 as Boda (2003a) argues.

\section{Conclusion}

This article proposes that the larger segment of Zechariah $7: 1-8: 23$ is a bridge (a transition from the preceding discourse to the subsequent discourse) that is connected to the prologue in 1:1-6 and is developed and expanded in the subsequent discourses. In this respect, the larger segment of 7:1-8:23 functions also as another introduction (for the prologue of 1:1-6) to the subsequent discourses (9:1-14:21). The larger segment (7:1-8:23) is related to the first larger segment (1:1-6), which functions as a prologue to the subsequent discourses (the visions and oracles in the following larger segment, 1:76:15). Israel's disobedience that resulted in Yahweh's wrath and judgement and Yahweh's exhortation to return to him are themes repeated in each larger segment. Whilst 7:1-8:23 is connected with 1:1-6 as the prologue and repeats the themes of 1:1-6 (cf. Boda 2003a:402), 7:1-8:23 develops some of the themes in 1:1-6 with newly asserted information articulating the future ('on that day') when Yahweh will come. At the same time, the themes in the larger segment of 7:1-8:23 are developed in the subsequent discourses (9:1-14:21).

\section{Acknowledgements Competing interests}

The authors declare that they have no financial or personal relationship(s) that may have inappropriately influenced them in writing this article.

\section{Authors' contributions}

This article is a reworked version reproduced from an aspect in Y.I.'s (University of Pretoria) PhD dissertation prepared under the supervision of P.M.V. (University of Pretoria).

\section{References}

Assis, E., 2010, 'Zechariah 8 as revision and digest of Zechariah 1-7', The Journal of Hebrew Scriptures 10, 1-16.

Baldwin, J.G., 1972, Haggai, Zechariah, Malachi: An introduction and commentary, InterVarsity, Downers Grove.

Beekman, J., Callow, J. \& Kopesec, M., 1981, The semantic structure of written communication, Summer Institute of Linguistics, Dallas.

Boda, M.J., 2003a, 'From fast to feasts: The literary function of Zechariah 7-8', The Catholic Biblical Quarterly 65, 390-407.

Boda, M.J., 2003b, Haggai \& Zechariah research: A bibliographic survey, Deo, Leiden.

Boda, M.J., 2003c, 'Majoring on the minors: Recent research on Hagga and Zechariah', Currents in Biblical Research 2, 33-68. http://dx.doi. org/10.1177/1476993×0300200103

Boda, M.J., 2004, The NIV application commentary: Haggai, Zechariah, Zondervan, Grand Rapids.

Brown, G. \& Yule, G., 1983, Discourse analysis, Cambridge textbooks in linguistics, Cambridge University Press, Cambridge. http://dx.doi.org/10.1017/ CB09780511805226

Butterworth, M., 1992, 'Structure and the book of Zechariah', Journal for the Study of the Old Testament, suppl. 130

Chafe, W.L., 1979, 'The flow of thought and the flow of language', in T. Givón (ed.) Syntax and semantics, vol, 12, Discourse and syntax, pp. 159-181, Academic Press, New York.
Childs, B.S., 1979, Introduction to the Old Testament as Scripture, Fortress, Philadelphia.

Clark, D.J., 1985, 'Discourse structure in Zechariah 7.1-8.23', The Bible Translator 36, 328-35.

Coggins, R.J., 1987, Haggai, Zechariah, Malachi, Sheffield Academic Press, Sheffield. (Old Testament Guides).

Conrad, E.W., 1999, Zechariah, Sheffield Academic Press, Sheffield.

Floor, S.J., 2004, 'From information structure, topic and focus, to theme in Biblical Hebrew narrative', PhD thesis, University of Stellenbosch.

Floyd, M.H., 2000, Minor prophets, part 2, Eerdmans, Grand Rapids. (The Forms of Old Testament Literature Series 22).

Floyd, M.H., 2002, 'The aFm (Maśśá') as a type of prophetic book', Journal of Biblical Literature 121, 401-422. http://dx.doi.org/10.2307/3268153

Fraser, B., 1990, 'An approach to discourse markers', Journal of Pragmatics 14, 383395. http://dx.doi.org/10.1016/0378-2166(90)90096-V

Frolov, S., 2005, 'Is the narrator also among the prophets?: Reading Zechariah without presuppositions', Biblical Interpretation 13, 13-40. http://dx.doi. org/10.1163/1568515053279166

Givón, T., 1990, Syntax: A functional-typological introduction, vol. 2, John Benjamins, Amsterdam.

Goldfajn, T., 1998, Word order and time in Biblical Hebrew narrative, Clarendon Press, Oxford. (Oxford Theological Monographs). http://dx.doi.org/10.1093/acprof:o so/9780198269533.001.0001

Goutsos, D., 1997, Modelling discourse topic: Sequential relations and strategies in expository text, Ablex, Norwood.

Gundel, J.K., 1988, The role of topic and comment in linguistic theory, Garland Publishing, New York.

Hanson, P.D., 1975, The dawn of apocalyptic, Fortress, Philadelphia.

Hartle, J.A., 1992, 'The literary unity of Zechariah', Journal of the Evangelical Theological Society 35, 145-157.

Hayes, E.R., 2004 “"Hearing Jeremiah": Perception and cognition in Jeremiah 1:1-2:2', Hebrew Studies 35, 99-119. http://dx.doi.org/10.1353/hbr.2004.0005

Hayes, E.R., 2008, The pragmatics of perception and cognition in MT Jeremiah 1:1-6:30: A cognitive linguistics approach, Berlin and New York, De Gruyter. (Beihefte zur Zeitschrift für die alttestamentliche Wissenschaft 380).

Hwang, S.J.J., 1989, 'Recursion in the paragraph as a unit of discourse development', Discourse Processes 12, 461-477. http://dx.doi.org/10.1080/01638538909544740

Kim, M-H., 2002, 'Thematic management in Korean narrative', in M. Louwerse \& W. van Peer (eds.), Thematics: Interdisciplinary studies, pp. 137-156, John Benjamins, Amsterdam. (Converging Evidence in Language and Communication Research 3).

Kline, M.G., 1991, 'The structure of the book of Zechariah', Journal of the Evangelical Theological Society 34, 179-193.

Lambrecht, K., 1994, Information structure and sentence form: Topic, focus and the mental representations of discourse referents, Cambridge University Press, Cambridge. (Cambridge Studies in Linguistics 71). http://dx.doi.org/10.1017/ CB09780511620607

Longacre, R.E., 1996, The grammar of discourse, Topics in language and linguistics, Plenum Press, New York. http://dx.doi.org/10.1007/978-1-4899-0162-0

Lowery, K.E., 1985, 'Toward a discourse grammar of Biblical Hebrew', PhD thesis, University of Michigan.

Mason, R., 1973, 'The use of earlier Biblical material in Zechariah IX-XIV: A study in inner Biblical exegesis', PhD dissertation, University of London. (Reprinted in Boda, M. \& Floyd M.H. (eds.), 2003, 'Bringing out the Treasure', Journal for the Boda, M. \& Floyd M.H. (eds.), 2003, 'Bringing out the
Study of the Old Testament suppl. ser. 370, 201-209).

Mason, R., 1976, 'The relation of Zechariah 9-14 to Proto-Zechariah', Zeitschift für die alttestamentliche Wissenschaft 88, 227-239.

Miller, C.L., 1999, 'The pragmatics of waw as a discourse marker in Biblical Hebrew dialogue', Zeitschrift für Althebraistik 12, 165-191.

Meyers, C.L. \& Meyers, E., 1987, Haggai-Zechariah 1-8, Doubleday, New York. (The Anchor Bible 25B).

Meyers, C.L. \& Meyers, E., 1993, Zechariah 9-14, Doubleday, New York. (The Anchor Bible 25C).

Moseman, R.D., 2000, 'Reading the two Zechariahs as one', Review and Expositor 97, 487-498.

Moseman, R.D., 2009, 'The date formulae in the book of Zechariah: An important key for interpreting Zechariah', Review and Expositor 106, 575-589.

Petterson, A.R., 2009, 'Behold your king: The hope for the house of David in the book of Zechariah', Journal for the Study of the Old Testament, suppl. ser. 513,

Pierce, R.W., 1984a, 'Literary connectors and a Haggai/Zechariah/Malachi corpus', Journal of the Evangelical Theological Society 27, 279-288.

Pierce, R.W., 1984b, 'A thematic development of the Haggai/Zechariah/Malachi corpus', Journal of the Evangelical Theological Society 27, 401-411.

Plöger, O., 1968, Theocracy and eschatology, transl. S. Rudman, Blackwell, Oxford.

Polanyi, L., 1982, 'Linguistic and social constraints on storytelling', Journal of Pragmatics 6, 509-524. http://dx.doi.org/10.1016/0378-2166(82)90023-6 
Portnoy, S.L. \& Petersen, D.L., 1984, 'Biblical texts and statistical analysis: Zechariah and beyond', Journal of Biblical Literature 103, 11-21. http://dx.doi. org/10.2307/3260311

Redditt, P.L., 1995, Haggai, Zechariah, Malachi, Eerdmans, Grand Rapids.

Redditt, P.L., 2003, 'Zechariah 9-14: The capstone of the book of the Twelve', in M Floyd (ed.), Bringing out the Treasure: Inner Biblical Allusion in Zechariah 9-14, pp. 305-332, Sheffield, Sheffield Academic Press. (Journal of the Study of the Old Testament Supplement 370).

Redditt, P.L., 2008, Introduction to the prophets, Eerdmans, Grand Rapids.

Schaefer, K., 1993, 'Zechariah 14 and the composition of the book of Zechariah', Revue Biblique 100, 368-398.

Segal, E.M., Duchan, J.F. \& Scott, P.J., 1991, 'The role of interclausal connectives in narrative structuring: Evidence form adults' interpretations of simple stories', Discourse Processes 14, 27-54. http://dx.doi.org/10.1080/01638539109544773
Smith, R.L., 1984, Micah-Malachi, Word, Waco. (Word Biblical Commentary 32).

Sweeney, M.A., 2000, The twelve prophets, vol. 2: Micah, Nahum, Habakkuk, Zephaniah, Haggai, Zechariah, Malachi, Liturgical Press, Collegeville.

Tollington, J.E., 1993, 'Tradition and innovation in Haggai and Zechariah 1-8', Journa for the Study of the Old Testament, suppl. 150.

Van der Merwe, C.H.J., Naudé J.A. \& Kroeze, J.H., 1999, Biblical Hebrew reference grammar, Sheffield Academic Press, Sheffield.

Van der Merwe, C.H.J. \& Talstra, E., 2003, 'Biblical Hebrew word order: The interface of information structure and formal features', Zeitschrift für Althebraistik 16 , 68-107.

Van Dijk, T.A. \& Kintsch, W., 1983, Strategies of discourse comprehension, Academic Press, New York.

Van Dyke Parunak, H., 1983, 'Transitional techniques in the Bible', Journal of Biblical Literature 102, 525-548. http://dx.doi.org/10.2307/3260864 